Article

\title{
Apple Tree Responses to Deficit Irrigation Combined with Periodic Applications of Particle Film or Abscisic Acid
}

\author{
Khalid M. Al-Absi ${ }^{1}$ and Douglas D. Archbold ${ }^{2, *}$ \\ 1 Department of Plant Production, Faculty of Agriculture, Mu'tah University, Al-Karak 61710, Jordan; \\ absikhal@mutah.edu.jos \\ 2 Department of Horticulture, University of Kentucky, Lexington, KY 40546, USA \\ * Correspondence: darchbol@uky.edu; Tel.: +1-859-278-0576
}

Academic Editor: Arturo Alvino

Received: 8 August 2016; Accepted: 17 October 2016; Published: 20 October 2016

\begin{abstract}
The objective of this study was to determine if the application of two antitranspirant compounds would moderate water deficit stress effects on physiological responses of "Granny Smith", "Royal Gala" and "Golden Delicious" apple (Malus domestica Borkh.) trees on MM106 rootstock that occur during deficit irrigation. Uniform trees were grown in pots under water supply regimes of $30 \%, 60 \%$, and $80 \%$ depletion of available water (DAW) before irrigation to runoff and received applications of kaolin particle film (PF) or abscisic acid (ABA) at 0, 30 and 60 days. At 120 days, genotype and deficit irrigation affected nearly all leaf traits, but antitranspirant treatment had no significant effects. As the \% DAW increased, the net photosynthetic rate (Pn), transpiration rate $(\mathrm{T})$, stomatal conductance, leaf water and pressure potential, variable-to-maximal chlorophyll fluorescence, leaf number, and leaf N, P and K contents were reduced. A significant genotype by deficit irrigation interaction was evident on $\mathrm{T}$, water use efficiency (WUE), and leaf osmotic pressure potential. A significant deficit irrigation by antitranspirant interaction was evident on only leaf Pn, with PF and ABA reducing it at 30\% DAW and only PF reducing it at $80 \%$ DAW. However, the periodic use of PF or ABA during deficit irrigation did not alleviate most physiological effects of water deficit stress due to deficit irrigation.
\end{abstract}

Keywords: water deficit; kaolin; abscisic acid; leaf gas exchange; leaf water relations; chlorophyll fluorescence

\section{Introduction}

Drought is a critical environmental stress that disrupts crop growth and performance that will be exacerbated as the climate changes [1]. To avoid water deficits that reduce crop production, irrigation is applied, but water availability is the main limiting factor for productive agriculture in most arid and semi-arid regions. In Jordan, it has been estimated that crop irrigation utilizes about $70 \%$ of the total demand for water [2]. As the population grows and demand increases, the water available to agriculture will decline. Irrigation below the evapotranspiration (ET) requirements of a crop is considered deficit irrigation. If the water available for irrigation declines, deficit irrigation may become more common [3].

Plant species respond to water deficits through molecular changes, biochemical and physiological modifications, and ultimately morphological adaptations [4]. Plants have developed three major drought-resistance strategies in their adaptation to drought stress, including drought tolerance, drought avoidance, and drought escape [5]. Under water deficit conditions, most plant species close their stomata and modulate their leaf area (drought avoidance), adjusting the loss of water from the canopy, 
and may osmotically adjust (drought tolerance) [6]. Drought escape, completing the life cycle prior to severe stress, is most common in annual plant species.

Apple (Malus domestica Borkh.) is one of most widely grown and valuable deciduous fruit crops worldwide, and is extensively grown in the arid southern regions of Jordan. Several selection criteria have been proposed for identifying drought-tolerant genotypes based on their performance in stress and non-stress environments. Differences in canopy structure and water use efficiency (WUE) [7], as well as in leaf water potential $\left(\Psi_{\mathrm{w}}\right)$, osmotic adjustment, net photosynthetic rate (Pn), and stomatal conductance $\left(g_{s}\right)$ [8], may be responsible to varying extents in determining how a genotype/rootstock combination responds to drought. A significant genotypic influence of apple rootstock tolerance to water stress has been reported [8-10]. Considerable variation among different apple genotypes has also been identified for a range of physiological and biochemical characteristics including responses to water stress [11,12]. Vegetative growth is drastically reduced as a result of water deficit stress. This growth reduction has been attributed to reduced $\mathrm{Pn}, \mathrm{g}_{\mathrm{s}}$, and leaf $\Psi_{\mathrm{w}}$ [7]. In contrast, moderate water deficits have been shown to improve apple fruit quality with increased mean fruit weight, return bloom, flesh firmness, red skin color intensity [13], and total soluble solids content [11].

Deficit irrigation strategies can be useful for reducing water use and for managing fruit tree growth and yield [14]. Deficit irrigation has reduced apple tree growth without reducing fruit yield in some studies [15-17], but the effect may not be consistent year to year, as fruit yield has declined in other work $[18,19]$. As water deficit stress increases, negative impacts on yield are more likely, but finding the optimum deficit irrigation strategy may be challenging as environmental conditions (i.e., ambient temperature, relative humidity/vapor pressure deficit, sunny versus cloudy conditions) vary from season to season.

Numerous compounds have been studied as tools to alleviate water deficit stress by reducing the rate of leaf water loss. Foliar application of kaolin mineral particle film (PF) was reported to protect plants against drought stress [20-23]. Seasonal use in apple orchards increased Pn and T by reducing heat stress on leaves $[20,21]$. Abscisic acid (ABA) application reduces transpiration and stimulates osmotic adjustment in plants [24]. Exogenous application of ABA has reduced $\mathrm{T}$ and enhanced drought tolerance in several plant species [25-29]. Increasing the endogenous foliar ABA content in apple by inhibiting its hydroxylation improved physiological and biochemical aspects of tree drought tolerance [30].

Many studies of the effects of drought stress and antitranspirant application have been conducted for a relatively short duration, only a few weeks [12,31,32]. This approach can successfully expose incipient physiological and biochemical drought stress effects and drought tolerance responses. Fewer studies have looked at longer-term effects on physiological and biochemical responses. As trees develop drought avoidance modifications over longer periods, it is not clear if drought tolerance responses might also be adapting to the modified status. Whether deficit irrigation strategies are by choice to manage tree growth or are imposed by limited water availability, antitranspirants could be useful for alleviating some of the effects of drought stress. PF use in wine grapes has reduced the effects of moderate water stress during deficit irrigation [33,34], but there have been no reports examining this possibility with apple using either PF or ABA.

Results of container [25] and parallel field [11] experiments, in addition to those of other investigators [35], clearly demonstrated that water deficit stress caused plants to reduce Pn and, ultimately, growth. The response was strongly affected by the rapidity, severity and duration of the water shortage. In view of these results, and the need to minimize water stress effects during deficit irrigation of apple, the objective of this work was to study responses of three apple genotypes, "Granny Smith", "Royal Gala" and "Golden Delicious", grafted on MM106 rootstock, all common in Jordan, to scheduled use of PF and ABA during deficit irrigation, hypothesizing that the antitranspirants would moderate water deficit stress effects on leaf water relations, gas exchange, chlorophyll fluorescence properties, mineral composition, and leaf production. 


\section{Materials and Methods}

This study was carried out in a greenhouse located in the Department of Horticulture, College of Agriculture, University of Kentucky, Lexington, KY, USA, from November 2010 to June 2011. The greenhouse was $22 \pm 6{ }^{\circ} \mathrm{C}$ with ambient light levels during the investigation. Uniform, one year-old, dormant "Granny Smith", "Royal Gala" and "Golden Delicious" apple scions grafted on MM106 rootstock (Vaughn Nursery, McMinnville, TN, USA), were used. The leader shoots were pruned to a height of $90 \mathrm{~cm}$, lateral branches were removed, the roots were pruned to a uniform length, and the trees were planted in $14.4 \mathrm{~L}$ black poly containers filled with Barky Beaver medium (composed of hardwood bark fines, pine park fines and peat moss, pH 5.5-6.5) (Barky Beaver Mulch \& Soil Mix, Inc., Moss, TN, USA). The few floral buds present were removed when first evident during bud swell. The trees were irrigated uniformly, and were supplied with macro- and microelements (Peters Professional, Scotts-Sierra Horticultural Products Co., Marysville, OH, USA).

The trees were grown for two weeks prior to initiating the treatments. There were three replicate trees per irrigation level by antitranspirant treatment within each genotype, laid out in a randomized complete block design with three blocks (each on a separate greenhouse bench), each block with one replicate tree per treatment-genotype combination. Trees were subjected to one of the following irrigation treatments: Irrigation to runoff after $30 \%, 60 \%$, or $80 \%$ depletion of available water (DAW). The irrigation treatments were derived after field capacity and wilting point were determined by generating a pressure-volume curve. Based on these two points, the total volume of available water (between field capacity and the wilting point) was calculated, and the weight derived. Each container was then weighed every two days, and when the depletion of available water was $30 \% \pm 3 \%, 60 \% \pm 3 \%$, or $80 \% \pm 3 \%$ of the total, each was irrigated to field capacity. Kaolin-based particle film (Surround WP Crop Protectant, Engelhard Corporation, Iselin, NJ, USA) and abscisic acid (ABA; ProTone SG, Valent BioSciences Corporation, Libertyville, IL, USA, 20\% concentration, $w / w$ ), were used as antitranspirants. PF was applied at $6 \% \mathrm{w} / \mathrm{v}$ and $\mathrm{ABA}$ was applied at $5 \mathrm{mM}$ as sprays to run off of half of the trees of each irrigation treatment on three dates: At 0, 30, and 60 days after the initiation of the study. Untreated trees at each \% DAW constituted the controls. The trees were maintained under these conditions for 150 days.

Gas exchange measurements were taken when the assigned DAW was reached at or after 120 days after beginning the deficit irrigation treatments, between 9 a.m. and 1 p.m. The exact measurement date for each tree varied as the rate and severity of depletion differed. Measurements of net photosynthetic $\left(\mathrm{CO}_{2}\right.$ assimilation) rate $(\mathrm{Pn})$, transpiration rate $(\mathrm{T})$, and stomatal conductance $\left(\mathrm{g}_{\mathrm{s}}\right)$ were conducted on both the second and third intact, fully-expanded leaf from the apex of the terminal shoot of each replicate tree using a portable steady state infrared gas analyzer (LI-6400, LI-COR, Lincoln, NE, USA), and the means per tree derived for data analysis. The leaf surface area within the measurement chamber of the gas analyzer was $6 \mathrm{~cm}^{2}$, and the ambient $\mathrm{CO}_{2}$ concentration was adjusted to $352 \mu \mathrm{mol} \cdot \mathrm{mol}^{-1}$. Water use efficiency (WUE) was calculated as the instantaneous ratio of $\mathrm{Pn} / \mathrm{T}$.

Leaf water potential $\left(\Psi_{\mathrm{W}}\right)$ of two recent fully expanded, mature leaves on each replicate tree was measured using a pressure bomb (Model 610, PMS Instruments, Corvallis, OR, USA) as described by Zhang and Archbold [36]. Measurements were taken between 9 a.m. and 2 p.m. when the assigned DAW was reached as described above, at or after 120 days after beginning the deficit irrigation treatments. Each leaf was cut at the petiole base and immediately placed in the pressure chamber with about $5 \mathrm{~mm}$ of the cut end of the petiole protruding through the compressible rubber gland used to seal the chamber. Compressed $\mathrm{N}_{2}$ was released into the chamber until the sap returned to the cut end of the xylem, and the pressure required was recorded. For measuring leaf osmotic potential $\left(\Psi_{\pi}\right)$, the leaves were then sealed between two layers of parafilm and frozen at $-20^{\circ} \mathrm{C}$. Leaf discs with a diameter of the sample cups were taken with a cork borer, placed into a sample cup, and thawed for $1 \mathrm{~h}$ inside the sealed cup at room temperature. The cup was then placed in a chilled mirror dewpoint sensor (Model WP4-T, Decagon Devices, Pullman, WA, USA). Each sample was processed for 20 min 
at room temperature. Leaf pressure potential $\left(\Psi_{\mathrm{p}}\right)$ was calculated as the difference between $\Psi_{\mathrm{w}}$ and $\Psi_{\pi}$. The means per tree of each component of water potential were derived for data analysis.

Chlorophyll fluorescence, as a measure of injury to the photosynthetic apparatus, was obtained when the assigned DAW was reached, as described above, using a Plant Efficiency Analyzer (PEA; Hansatech Instruments Ltd., Kings Lynn, UK). Chlorophyll fluorescence (as the Fv/Fm ratio) was measured on three dark-adapted leaves from each replicate tree. Dark-adaptation was achieved by covering the leaves for $30 \mathrm{~min}$ under plastic clips provided with the PEA. The mean per tree was derived for data analysis.

Two leaves were randomly collected from each replicate tree, when the assigned DAW was reached. The leaves were oven dried at $70{ }^{\circ} \mathrm{C}$ until a constant weight was obtained, combined, and ground to pass through a 20 mesh screen. Leaf mineral composition (N, P, K, Ca, and Mg) was determined as \% dry weight on samples collected at 120 days as described by Tandon [37].

The number of new leaves produced on each replicate tree during the course of the study was measured 150 days after beginning the deficit irrigation treatments as a measure of the treatment effects on tree growth.

Using means per replicate tree, the data were subjected to analysis of variance using MSTATC software. Significant effects and interactions were determined at a $P \leq 0.05$, and means were compared using the Least Significant Difference (LSD) test.

\section{Results}

\subsection{Main Effects}

Genotype and deficit irrigation but not antitranspirant application affected nearly all leaf traits (Table 1). The most notable exceptions were the lack of genotype differences in Pn, and of any main effects or interactions on leaf Ca or Mg content.

Table 1. $P$-values from analysis of variance for the main effects of genotype (G), deficit irrigation (I), and antitranspirant (A) application and their interactions on leaf traits. Leaf traits are: Net photosynthetic rate $(\mathrm{Pn})$, transpiration rate $(\mathrm{T})$, stomatal conductance $\left(\mathrm{g}_{\mathrm{s}}\right)$, water use efficiency (WUE), water, osmotic, and pressure potential $\left(\Psi_{\mathrm{w}}, \Psi_{\pi}\right.$ and $\Psi_{\mathrm{p}}$, respectively), ratio of variable-to-minimum chlorophyll fluorescence (Fv/Fm), N, P, K, Ca, and Mg content, and leaf number per tree. Measurements were taken at the completion of a final depletion cycle ending 120 or more days after starting the study but prior to re-watering. NS indicates the $P$-value was greater than 0.05 .

\begin{tabular}{|c|c|c|c|c|c|c|c|}
\hline \multirow{2}{*}{ Leaf Trait } & \multicolumn{7}{|c|}{ Main Effects and Interactions } \\
\hline & G & $\mathbf{I}$ & $\mathbf{A}$ & $\mathbf{G} \times \mathbf{I}$ & $\mathbf{G} \times \mathbf{A}$ & $\mathbf{I} \times \mathbf{A}$ & $\mathbf{G} \times \mathbf{I} \times \mathbf{A}$ \\
\hline Pn & NS & $<10^{-4}$ & NS & NS & NS & 0.0082 & NS \\
\hline $\mathrm{T}$ & $<10^{-4}$ & $<10^{-4}$ & NS & 0.0002 & NS & NS & NS \\
\hline $\mathrm{g}_{\mathrm{s}}$ & 0.0037 & $<10^{-4}$ & NS & NS & NS & NS & NS \\
\hline WUE & 0.0001 & $<10^{-4}$ & NS & 0.0180 & NS & NS & NS \\
\hline$\Psi_{\mathrm{W}}$ & 0.0091 & $<10^{-4}$ & NS & NS & NS & NS & NS \\
\hline$\Psi_{\pi}$ & 0.0321 & $<10^{-4}$ & NS & 0.0189 & NS & NS & NS \\
\hline$\Psi_{p}$ & 0.0346 & $<10^{-4}$ & NS & NS & NS & NS & 0.0255 \\
\hline $\mathrm{Fv} / \mathrm{Fm}$ & 0.0091 & $<10^{-4}$ & NS & NS & NS & NS & NS \\
\hline Leaf Number & $<10^{-4}$ & $<10^{-4}$ & NS & NS & NS & NS & NS \\
\hline $\mathrm{N}$ & 0.0002 & $<10^{-4}$ & NS & NS & NS & NS & NS \\
\hline $\mathrm{P}$ & $<10^{-4}$ & 0.0001 & NS & 0.0025 & NS & NS & NS \\
\hline $\mathrm{K}$ & 0.0051 & $<10^{-4}$ & NS & NS & NS & NS & NS \\
\hline $\mathrm{Ca}$ & NS & NS & NS & NS & NS & NS & NS \\
\hline $\mathrm{Mg}$ & NS & NS & NS & NS & NS & NS & NS \\
\hline
\end{tabular}

\subsection{Leaf Gas Exchange}

Differences among genotypes were evident in $\mathrm{T}, \mathrm{g}_{\mathrm{s}}$, and WUE, but not Pn (Tables 1 and 2, Figure 1). The transpiration rate was the lowest and the WUE was the highest for "Granny Smith", 
and "Royal Gala" had the highest stomatal conductance. Deficit irrigation reduced Pn, $\mathrm{T}$, and $\mathrm{g}_{\mathrm{s}}$ as $\%$ DAW increased. Pn and T at $80 \%$ DAW were reduced $64.9 \%$ and $67.5 \%$, respectively, compared to $30 \%$ DAW, and were also lower than those at $60 \%$ DAW. WUE was greater at $60 \%$ DAW than at $30 \%$ and $80 \%$ DAW.

Table 2. Main effect means for genotype and for deficit irrigation as dependent on reaching 30\%, $60 \%$, or $80 \%$ depletion of available water (DAW) prior to re-watering on leaf gas exchange. Measurements were taken at the completion of a final depletion cycle ending 120 or more days after starting the study but prior to watering.

\begin{tabular}{ccccccc}
\hline \multirow{2}{*}{ Leaf Trait } & \multicolumn{3}{c}{ Genotype } & \multicolumn{3}{c}{ Deficit Irrigation (\% DAW) } \\
\cline { 2 - 7 } & GS & RG & GD & 30 & $\mathbf{6 0}$ & $\mathbf{8 0}$ \\
\hline $\begin{array}{c}\text { Photosynthesis }(\mathrm{Pn}) \\
\left(\mu \mathrm{mol} \cdot \mathrm{CO}_{2} \cdot \mathrm{m}^{-2} \cdot \mathrm{s}^{-1}\right)\end{array}$ & $10.0 \mathrm{NS}$ & 9.7 & 9.4 & $13.6 \mathrm{a}$ & $11.2 \mathrm{~b}$ & $4.3 \mathrm{c}$ \\
$\begin{array}{c}\text { Transpiration }(\mathrm{T})\left(\mathrm{mmol} \cdot \mathrm{H}_{2} \mathrm{O} \cdot \mathrm{m}^{-2} \cdot \mathrm{s}^{-1}\right) \\
\text { Stomatal conductance }\left(\mathrm{g}_{\mathrm{s}}\right)\end{array}$ & $2.50 \mathrm{c}$ & $3.06 \mathrm{a}$ & $2.92 \mathrm{~b}$ & $4.14 \mathrm{a}$ & $2.67 \mathrm{~b}$ & $1.67 \mathrm{c}$ \\
$\left(\mathrm{mmol} \cdot \mathrm{H}_{2} \mathrm{O} \cdot \mathrm{m}^{-2} \cdot \mathrm{s}^{-1}\right)$ & $0.217 \mathrm{~b}$ & $0.254 \mathrm{a}$ & $0.217 \mathrm{~b}$ & $0.261 \mathrm{a}$ & $0.265 \mathrm{a}$ & $0.162 \mathrm{~b}$ \\
Water use efficiency $(\mathrm{Pn} / \mathrm{T})$ & $4.04 \mathrm{a}$ & $3.20 \mathrm{~b}$ & $3.29 \mathrm{~b}$ & $3.34 \mathrm{~b}$ & $4.37 \mathrm{a}$ & $2.81 \mathrm{~b}$ \\
\hline
\end{tabular}

Means followed by different letters for each trait within genotype or irrigation timing were significantly different by Fisher's Least Significant Difference (LSD) test at $P \leq 0.05$.
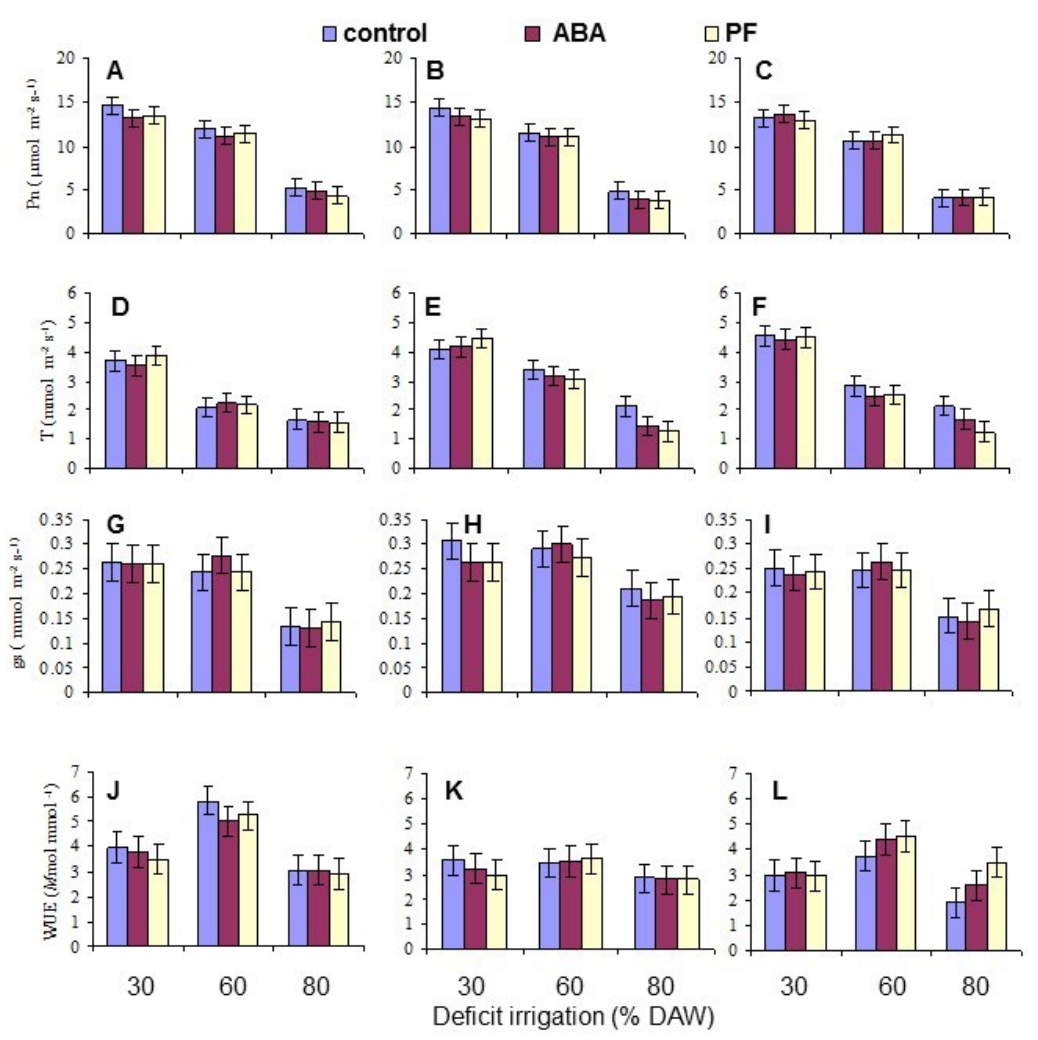

Figure 1. Effects of deficit irrigation as \% depletion of available water (DAW) before re-watering and antitranspirant (ABA or PF) application on "Granny Smith" (A,D,G,J), "Royal Gala" (B,E,H,K), and "Golden Delicious" (C,F,I,L) apple net photosynthetic rate $(\mathrm{Pn})(\mathbf{A}-\mathbf{C})$, transpiration rate $(\mathrm{T})(\mathbf{D}-\mathbf{F})$, stomatal conductance $\left(\mathrm{g}_{\mathrm{s}}\right)(\mathbf{G}-\mathbf{I})$, and water use efficiency (WUE) (J-L). Values are the means \pm standard error of the mean of three replicate measurements taken at the completion of a final depletion cycle ending 120 or more days after starting the study but prior to re-watering.

A significant genotype by deficit irrigation interaction was evident on T and WUE (Table 3). At 30\% DAW, "Royal Gala" and "Golden Delicious" had higher T values than "Granny Smith", 
and the genotypes differed from one another at 60\% DAW with "Royal Gala" the highest, followed by "Golden Delicious" and with "Granny Smith" the lowest, while they were all low at $80 \%$ DAW. Differences among genotypes were also evident in WUE, although in the opposite pattern. "Granny Smith" had the highest WUE at 30\% and 60\% DAW, and was equal to "Royal Gala" but higher than "Golden Delicious" at 80\% DAW. WUE increased from 30\% to 60\% DAW for both "Granny Smith" and "Golden Delicious", but not for "Royal Gala", and it declined from 60\% to 80\% DAW for all genotypes. Reductions in Pn and/or T and an increase in WUE can be effective responses to avoid water deficit stress $[11,12,31]$. These reductions in Pn and T have been ascribed to increased mesophyll resistance and decreased leaf cell metabolic activity [38].

Averaged across genotypes, there was an interaction of the antitranspirant treatment with the irrigation level on Pn (Table 4). ABA and PF reduced Pn at 30\% DAW, and PF but not ABA reduced it at $80 \%$ DAW, though all of the effects were small compared to the main effects of the irrigation level. Failure of ABA to affect T was observed in mulberry (Morus alba L.) [39], and PF-treated apple [40,41], and pecan (Carya illinoinensis) [42]. However, the reflective properties of the kaolin PF reduced leaf temperature by increasing leaf reflectance in field-grown trees, thus reducing leaf temperature, $\mathrm{T}$, and the leaf-to-air vapor pressure gradient in other studies [20-22,43,44]. Gas exchange responses to $\mathrm{PF}$ were only evident at vapor pressure deficits less than $2 \mathrm{kPa}$ [21], which could have contributed to the inconsistencies among studies.

Table 3. Interaction of genotype with deficit irrigation as dependent on reaching $30 \%, 60 \%$, or $80 \%$ depletion of available water (DAW) prior to re-watering on transpiration rate, water use efficiency, and leaf osmotic potential $\left(\Psi_{\pi}\right)$. Measurements were taken at the completion of a final depletion cycle ending 120 or more days after starting the study but prior to watering.

\begin{tabular}{cccc}
\hline \multirow{2}{*}{ Genotype } & \multicolumn{3}{c}{ Deficit Irrigation (\% DAW) } \\
\cline { 2 - 4 } & \multicolumn{3}{c}{ Transpiration $\left(\mathrm{mmol} \cdot \mathrm{H}_{2} \mathrm{O} \cdot \mathrm{m}^{-2} \cdot \mathrm{s}^{-1}\right)$} \\
\hline Granny Smith & $3.70 \mathrm{~b}$ & $2.17 \mathrm{e}$ & $1.63 \mathrm{f}$ \\
Royal Gala & $4.23 \mathrm{a}$ & $3.23 \mathrm{c}$ & $1.70 \mathrm{f}$ \\
Golden Delicious & $4.50 \mathrm{a}$ & $2.60 \mathrm{~d}$ & $1.67 \mathrm{f}$ \\
\hline & Water use efficiency $($ net photosynthetic rate/transpiration rate) \\
\hline Granny Smith & $3.74 \mathrm{c}$ & $5.37 \mathrm{a}$ & $3.01 \mathrm{ef}$ \\
Royal Gala & $3.26 \mathrm{de}$ & $3.54 \mathrm{~cd}$ & $2.78 \mathrm{fg}$ \\
Golden Delicious & $3.00 \mathrm{ef}$ & $4.22 \mathrm{~b}$ & $2.66 \mathrm{~g}$ \\
\hline & \multicolumn{4}{c}{ Leaf osmotic potential $\left(\Psi_{\pi}, \mathrm{MPa}\right)$} \\
\hline Granny Smith & $-2.14 \mathrm{~d}$ & $-2.97 \mathrm{c}$ & $-3.71 \mathrm{a}$ \\
Royal Gala & $-1.79 \mathrm{e}$ & $-3.23 \mathrm{~b}$ & $-3.41 \mathrm{~b}$ \\
Golden Delicious & $-1.89 \mathrm{e}$ & $-2.91 \mathrm{c}$ & $-3.38 \mathrm{~b}$ \\
\hline
\end{tabular}

Means followed by different letters among all values within an interaction set were significantly different by Fisher's Least Significant Difference (LSD) test at $P \leq 0.05$.

Table 4. Interaction of antitranspirant with deficit irrigation as dependent on reaching $30 \%$, $60 \%$, or $80 \%$ depletion of available water (DAW) prior to re-watering on net photosynthetic rate and water use efficiency. Measurements were taken at the completion of a final depletion cycle ending 120 or more days after starting the study but prior to watering.

\begin{tabular}{cccc}
\hline \multirow{2}{*}{ Antitranspirant } & \multicolumn{3}{c}{ Deficit Irrigation (\% DAW) } \\
\cline { 2 - 4 } & $\mathbf{3 0}$ & $\mathbf{6 0}$ & $\mathbf{8 0}$ \\
\hline & Photosynthetic rate $\left(\mu \mathrm{mol} \cdot \mathrm{CO}_{2} \cdot \mathrm{m}^{-2} \cdot \mathrm{s}^{-1}\right)$ \\
\hline None & $14.1 \mathrm{a}$ & $11.4 \mathrm{c}$ & $4.6 \mathrm{~d}$ \\
Abscisic acid & $13.4 \mathrm{~b}$ & $11.0 \mathrm{c}$ & $4.3 \mathrm{~d}$ \\
Particle film & $13.2 \mathrm{~b}$ & $11.3 \mathrm{c}$ & $4.1 \mathrm{e}$ \\
\hline
\end{tabular}

Means followed by different letters among all values were significantly different by Fisher's Least Significant Difference (LSD) test at $P \leq 0.05$. 


\subsection{Leaf Water Relations}

A significant influence of genotype and deficit irrigation on leaf water relations was observed, but antitranspirants had no effect (Tables 1 and 5, Figure 2). While there were small differences among genotypes for leaf $\Psi_{\mathrm{w}}, \Psi_{\pi}$ and $\Psi_{\mathrm{p}}$, the values changed considerably under water deficit conditions. Leaf $\Psi_{\mathrm{w}}$ and $\Psi_{\pi}$ declined as the $\%$ DAW increased, but leaf $\Psi_{\mathrm{p}}$ declined at $80 \%$ DAW only. The only interaction of note on leaf water relations was a genotype by deficit irrigation effect on leaf $\Psi_{\pi}$ (Table 3). "Granny Smith" had the lowest leaf $\Psi_{\pi}$ at 30\% and 80\% DAW, while "Royal Gala" had the lowest at $60 \%$ DAW. Though not directly measured in the present work, osmotic adjustment under reduced irrigation has been observed in apple [12,32]. The low leaf $\Psi_{\pi}$ for specific genotypes at each \% DAW may have been evidence of genotypic differences in osmoregulation. The ability of apple trees to acclimate by active osmoregulation would be an advantage, providing increased flexibility in response to changing environmental conditions. The reduction in leaf $\Psi_{\mathrm{w}}$ as the moisture level decreased (i.e., from $30 \%$ to $80 \% \mathrm{DAW})$ in this investigation was correlated to lower $\mathrm{T}(r=0.87, P<0.05)$.

$\square$ control $\quad \square \mathrm{ABA} \quad \square \mathrm{PF}$
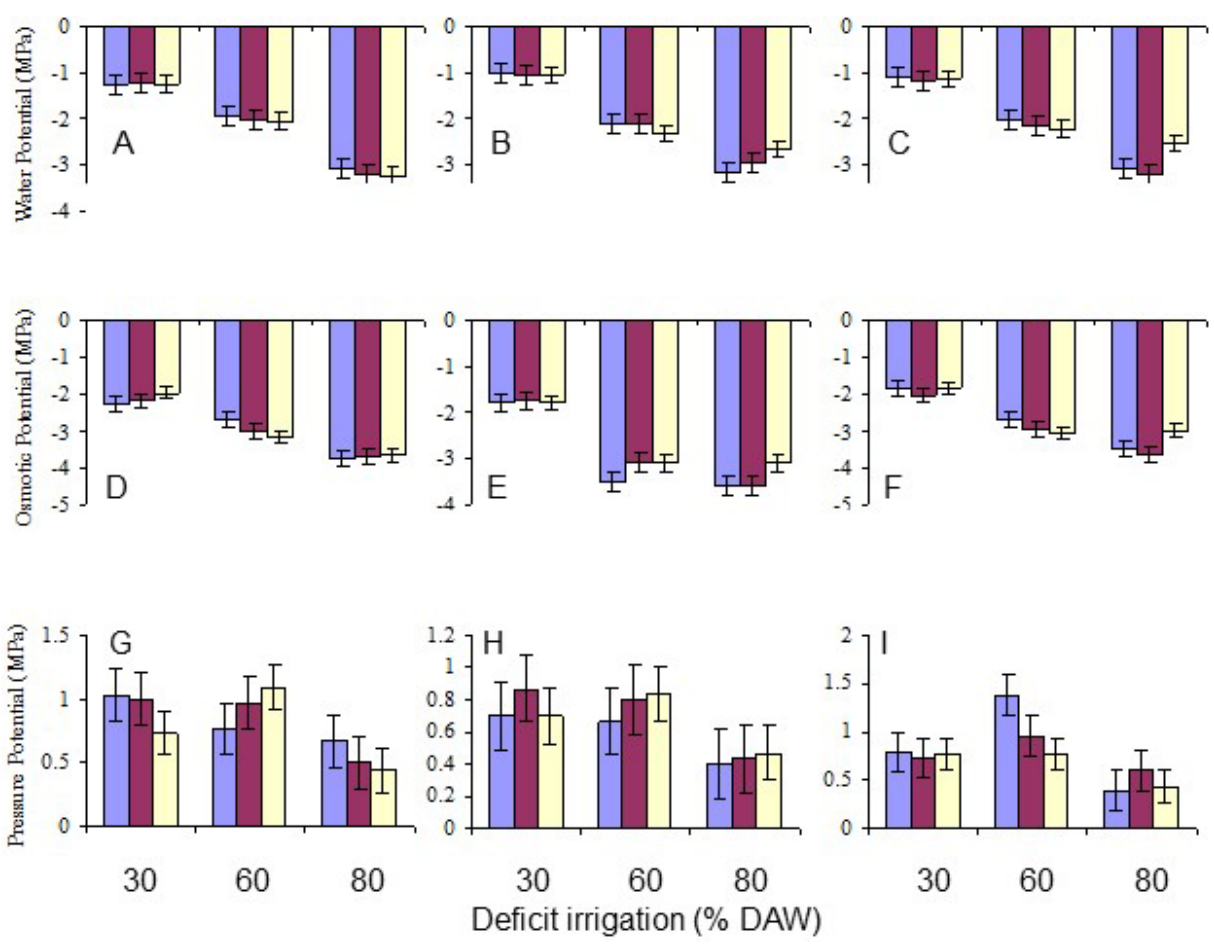

Figure 2. Effects of deficit irrigation as \% depletion of available water (DAW) before re-watering and antitranspirant (ABA or PF) application on "Granny Smith" (A,D,G), "Royal Gala" (B,E,H), and "Golden Delicious" (C,F,I) apple on leaf water potential $\left(\Psi_{\mathrm{w}}\right)(\mathbf{A}-\mathbf{C})$, osmotic potential $\left(\Psi_{\pi}\right)(\mathbf{D}-\mathbf{F})$, and pressure potential $\left(\Psi_{\mathrm{p}}\right)(\mathrm{G}-\mathbf{I})$. Values are the means \pm standard error of the mean of three replicate measurements taken at the completion of a final depletion cycle ending 120 or more days after starting the study but prior to re-watering. 
Table 5. Main effect means for genotype and for deficit irrigation as dependent on reaching 30\%, $60 \%$, or $80 \%$ depletion of available water (DAW) prior to re-watering on leaf water relations components. Measurements were taken at the completion of a final depletion cycle ending 120 or more days after starting the study but prior to watering.

\begin{tabular}{ccccccc}
\hline Leaf Water Relations & \multicolumn{3}{c}{ Genotype } & \multicolumn{3}{c}{ Deficit Irrigation (\% DAW) } \\
\hline Component $(\mathbf{M P a})$ & GS & RG & GD & $\mathbf{3 0}$ & $\mathbf{6 0}$ & $\mathbf{8 0}$ \\
\hline Water potential $\left(\Psi_{\mathrm{w}}\right)$ & $-2.14 \mathrm{a}$ & $-2.05 \mathrm{~b}$ & $-2.07 \mathrm{~b}$ & $-1.12 \mathrm{c}$ & $-2.12 \mathrm{~b}$ & $-3.02 \mathrm{a}$ \\
Osmotic potential $\left(\Psi_{\pi}\right)$ & $-2.94 \mathrm{a}$ & $-2.81 \mathrm{~b}$ & $-2.72 \mathrm{c}$ & $-1.94 \mathrm{~b}$ & $-3.04 \mathrm{a}$ & $-3.50 \mathrm{a}$ \\
Pressure potential $\left(\Psi_{\mathrm{p}}\right)$ & $0.80 \mathrm{a}$ & $0.76 \mathrm{a}$ & $0.65 \mathrm{~b}$ & $0.81 \mathrm{a}$ & $0.92 \mathrm{a}$ & $0.48 \mathrm{~b}$ \\
\hline
\end{tabular}

Granny Smith (GS); Royal Gala (RG); Golden Delicious (GD); Means followed by different letters for each trait within genotype or irrigation timing were significantly different by Fisher's Least Significant Difference (LSD) test at $P \leq 0.05$.

\subsection{Leaf Fv/Fm and Number}

Chlorophyll fluorescence arises from overexcitation of the photochemical system, acting as a protective mechanism allowing plants under stressed conditions to dissipate light energy and survive, and the Fv/Fm ratio indicates photosystem II efficiency (PSII) [45]. The maximum quantum yield of PSII, as measured by the Fv/Fm ratio, differed among genotypes and declined with increasing DAW (Tables 1 and 6, Figure 3). As a result, there was a correlation $(r=0.77, P<0.05)$ between leaf $\Psi_{\mathrm{w}}$ and $\mathrm{Fv} / \mathrm{Fm}$ values. Fernandez et al. [9] observed drought stress effects on chlorophyll fluorescence in apple as well, though they occurred after effects on Pn were evident in contrast to our results where both declined as the \% DAW increased. The influence of water deficit stress on chlorophyll fluorescence reflects effects on thylakoid membrane integrity and the relative efficiency of electron transport from PSII to photosystem I [46].

Although there were differences among genotypes for leaf number per tree (Tables 1 and 6, Figure 3), only $80 \%$ DAW reduced the number, indicating a significant impact of deficit irrigation on tree growth over the duration of the study. The reduction in leaf number at $80 \%$ DAW could be attributed to the reduction in the assimilate supply as Pn was lowest at $80 \% \mathrm{DAW}$, to a decline in cell division and enlargement and more leaf senescence [47], and/or to low leaf $\Psi_{p}$ [48].

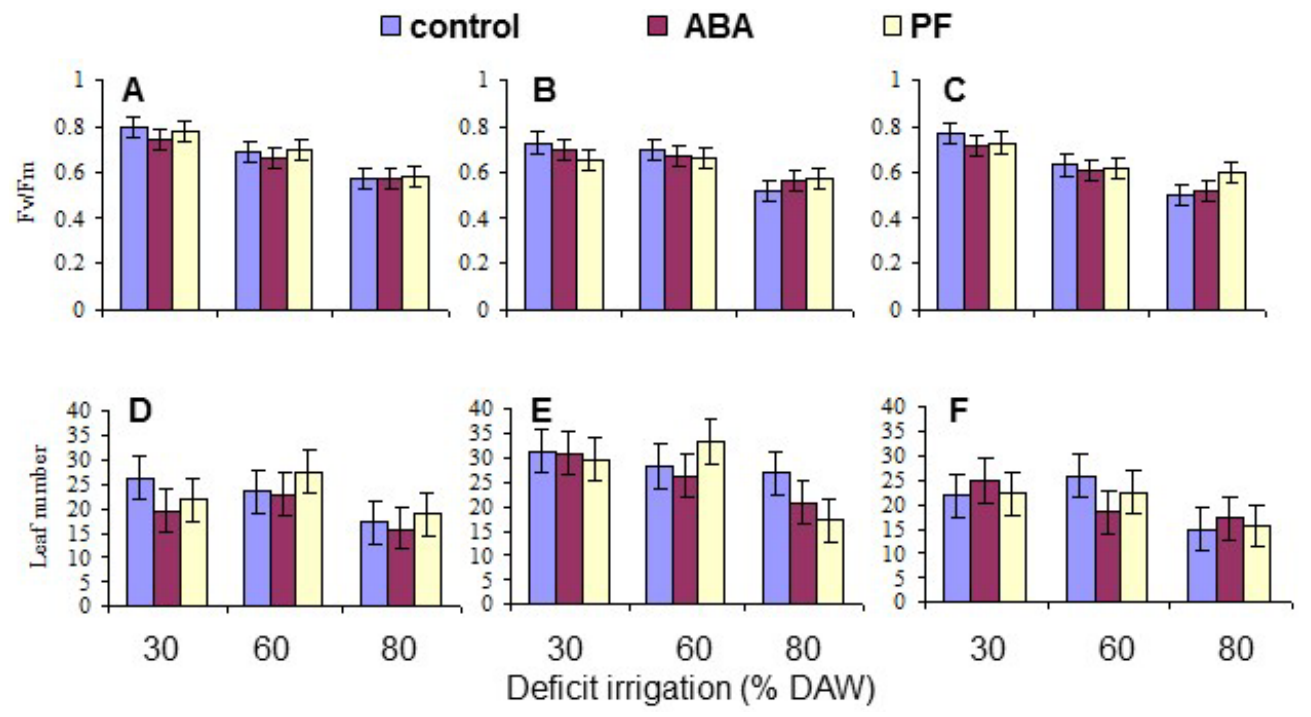

Figure 3. Effects of deficit irrigation as \% depletion of available water (DAW) before re-watering and antitranspirant (ABA or PF) application on "Granny Smith" (A,D), "Royal Gala" (B,E), and "Golden Delicious" (C,F) apple on leaf chlorophyll fluorescence (A-C) and leaf number per tree (D-F). Values are the means \pm standard error of the mean of three replicate measurements taken at the completion of a final depletion cycle ending 120 or more days after starting the study but prior to re-watering. 
Table 6. Main effect means for genotype and for deficit irrigation as dependent on reaching 30\%, $60 \%$, or $80 \%$ depletion of available water (DAW) prior to re-watering on leaf chlorophyll fluorescence, leaf number, and leaf N, P, and K content (as \% dry weight). Measurements were taken at the completion of a final depletion cycle ending 120 or more days after starting the study but prior to watering.

\begin{tabular}{ccccccc}
\hline \multirow{2}{*}{ Leaf Trait } & \multicolumn{3}{c}{ Genotype } & \multicolumn{3}{c}{ Deficit Irrigation (\% DAW) } \\
\cline { 2 - 7 } & GS & RG & GD & $\mathbf{3 0}$ & $\mathbf{6 0}$ & $\mathbf{8 0}$ \\
\hline Fv/Fm & $0.674 \mathrm{a}$ & $0.643 \mathrm{~b}$ & $0.634 \mathrm{c}$ & $0.737 \mathrm{a}$ & $0.661 \mathrm{~b}$ & $0.558 \mathrm{c}$ \\
Leaf number & $21.6 \mathrm{~b}$ & $27.2 \mathrm{a}$ & $20.5 \mathrm{~b}$ & $25.5 \mathrm{a}$ & $25.5 \mathrm{a}$ & $18.4 \mathrm{~b}$ \\
N content & $2.24 \mathrm{bc}$ & $2.34 \mathrm{ab}$ & $2.18 \mathrm{c}$ & $2.37 \mathrm{a}$ & $2.28 \mathrm{a}$ & $2.12 \mathrm{~b}$ \\
P content & $0.40 \mathrm{a}$ & $0.33 \mathrm{c}$ & $0.36 \mathrm{~b}$ & $0.38 \mathrm{a}$ & $0.37 \mathrm{~b}$ & $0.34 \mathrm{c}$ \\
K content & $2.09 \mathrm{a}$ & $1.91 \mathrm{~b}$ & $2.10 \mathrm{a}$ & $2.13 \mathrm{a}$ & $2.11 \mathrm{a}$ & $1.86 \mathrm{~b}$ \\
\hline
\end{tabular}

Granny Smith (GS); Royal Gala (RG); Golden Delicious (GD); Means followed by different letters for each trait within genotype or irrigation timing were significantly different by Fisher's Least Significant Difference (LSD) test at $P \leq 0.05$.

\subsection{Leaf N, P, and K Content}

The contents of $\mathrm{N}, \mathrm{P}$, and $\mathrm{K}$ were the only nutrients that varied among genotypes and deficit irrigation levels (Tables 1 and 6, Figure 4). Increasing deficit irrigation reduced leaf N, P, and K contents, with the most notable effects at 80\% DAW. Reductions in leaf N, P, and K contents in the stressed trees were likely affected by the decrease in T [31]. A low efficiency of nutrient absorption and transport within a plant has also been attributed to the slow movement of minerals in drying soil as well as to the decrease in root extension and root permeability [49].

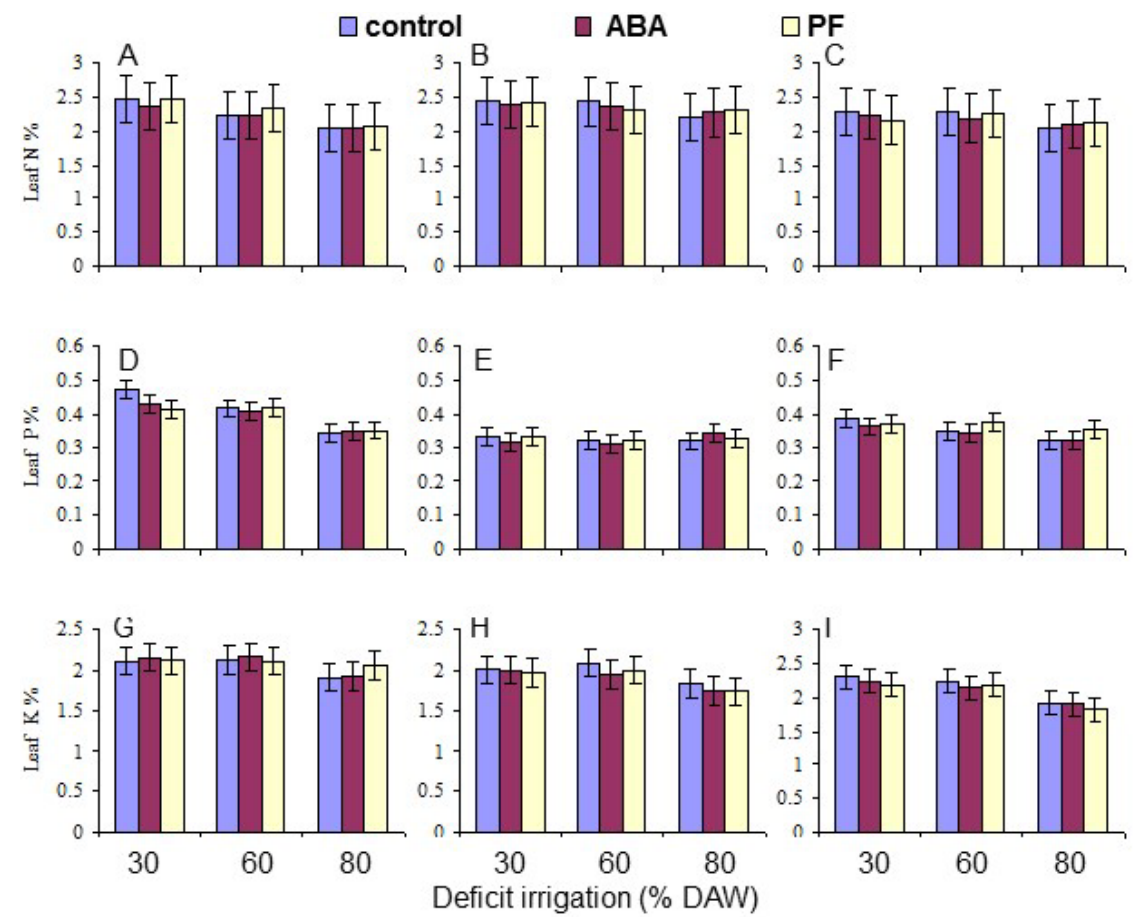

Figure 4. Effects of deficit irrigation as \% depletion of available water (DAW) before re-watering and antitranspirant (ABA or PF) application on "Granny Smith" (A,D,G), "Royal Gala" (B,E,H), and "Golden Delicious" (C,F,I) apple on leaf N (A-C), P (D-F), and K (G-I) content. Values are the means \pm standard error of the mean of three replicate measurements taken at the completion of a final depletion cycle ending 120 or more days after starting the study but prior to re-watering. 


\section{Discussion}

Overall, the water deficit stress at increasing \% DAW reduced Pn, T, leaf $\Psi_{\mathrm{w}}$ and $\Psi_{\pi}$, the Fv $/ \mathrm{Fm}$ ratio, and leaf N, P and K contents. WUE increased for two of the genotypes from $30 \%$ to $60 \%$ DAW because Pn did not change, but $g_{s}$ declined, and it decreased in all genotypes from $60 \%$ to $80 \%$ DAW. Apart from genotypic variation, deficit irrigation had the most important effect. PF affected leaf Pn but not the other gas exchange traits, suggesting it did not alter leaf physiology or development. The lack of response to ABA was likely due to the fact that only three applications were made to the trees. $\mathrm{ABA}$ metabolism would occur in leaves shortly after each application [50], and measurements reported here were taken 60 or more days after the last application, so ABA effects on stomatal closure or other physiological parameters would likely have subsided much earlier. More frequent ABA application might produce beneficial effects on gas exchange responses and WUE under stress conditions [27]. Nonetheless, there were no long-term effects from the ABA applications in the present work.

Under conditions of water scarcity, irrigation should be scheduled at a level of no less than $60 \%$ DAW, as this optimized WUE and maintained growth, as indicated by the leaf number, while detrimental effects on leaf gas exchange and growth occurred at $80 \%$ DAW. Even though there was a residue of kaolin PF on the leaves throughout the period of the study because the trees were only watered at their base, and the residue was never washed off as may occur in environments with periodic rainfall, there were no sustained effects on any measured trait other than leaf Pn mitigating the impact of reduced water availability. This was also evident in tree growth (as indicated by leaf production) which did not respond to PF. The effects of PF film on apple have been most notable in environments with high vapor pressure deficits and temperature, and with irrigated trees [20-23], quite different than the conditions of the present work. Although the trees in the present work were young and had limited root development and container volume which may have impacted the results, the application of PF to orchard-grown walnut (Juglans regia) also failed to mitigate the effects of water stress [43], so it is likely to have a similar impact on mature apple trees in the field.

\section{Conclusions}

Periodic use of PF or ABA during deficit irrigation did not alleviate water deficit stress effects from deficit irrigation strategies that impact apple tree growth under the conditions of this study.

Acknowledgments: This study was performed as a Fulbright Scholar during a sabbatical leave from University of Mu'tah, Jordan, and spent at the Department of Horticulture, University of Kentucky, KY, USA. The information reported in this paper (No. 16-11-093) is part of a project of the Kentucky Agricultural Experiment Station and is published with the approval of the Director.

Author Contributions: K.M.A. and D.D.A. conceived and designed the experiment; K.M.A. performed the experiment and analyzed the data; K.M.A. and D.D.A. wrote the paper.

Conflicts of Interest: The authors declare no conflict of interest.

\section{References}

1. Lobell, D.B.; Burke, M.B.; Tebaldi, C.; Mastrandrea, M.D.; Falcon, W.P.; Naylor, R.L. Prioritizing climate change adaptation needs for food security in 2030. Science 2008, 319, 607-610. [CrossRef] [PubMed]

2. Arar, A. Wastewater reuse for irrigation in the near east region. Water Sci. Technol. 1991, 23, 2127-2134.

3. Geerts, S.; Raes, D. Deficit irrigation as an on-farm strategy to maximize crop water productivity in dry areas. Agric. Water Manag. 2009, 96, 1275-1284. [CrossRef]

4. Aroca, R. Plant Responses to Drought Stress: From Morphological to Molecular Features; Springer: Berlin, Germany, 2012.

5. Ludlow, M.M. Strategies of response to water stress. In Structural and Functional Responses to Environmental Stress; Kree, K.H., Richter, H., Minckley, T.M., Eds.; SPB Academic: The Hague, The Netherlands, 1989; pp. 269-281.

6. Hanson, A.D.; Hitz, W.D. Metabolic responses of mesophytes to plant water deficits. Ann. Rev. Plant Physiol. 1982, 33, 163-203. [CrossRef] 
7. Li, F.; Cohen, S.; Naor, A.; Shaozong, K.; Erez, A. Studies of canopy structure and water use of apple trees on three rootstocks. Agric. Water Manag. 2002, 55, 1-14. [CrossRef]

8. Atkinson, C.J.; Policarpo, M.; Webster, A.D.; Kingswell, G. Drought tolerance of clonal Malus determined from measurements of stomatal conductance and leaf water potential. Tree Physiol. 2000, 20, 557-563. [CrossRef] [PubMed]

9. Fernandez, R.T.; Perry, R.L.; Flore, J.A. Drought response of young apple trees on three rootstocks. II. Gas exchange, chlorophyll fluorescence, water relations, and leaf abscisic acid. J. Am. Soc. Hortic. Sci. 1997, 122, 841-848.

10. Lombardini, L.; Toselli, M.; Flore, J.A. Carbon translocation and root respiration in potted apple trees during conditions of moderate drought. Acta Hortic. 2001, 557, 413-420. [CrossRef]

11. Mohawesh, O.E.; Al-Absi, K.M. Physiological response of two apple genotypes to different water regimes under semiarid conditions. Adv. Hortic. Sci. 2009, 23, 158-165.

12. Sircelj, H.; Tausz, M.; Grill, D.; Batic, F. Detecting different levels of drought stress in apple trees (Malus domestica Borkh.) with selected biochemical and physiological parameters. Sci. Hortic. 2007, 113, 362-369. [CrossRef]

13. Kilili, A.W.; Behboudian, M.H.; Mills, T.M. Composition and quality of "Braeburn" apples under reduced irrigation. Sci. Hortic. 1996, 67, 1-11. [CrossRef]

14. Behboudian, M.H.; Mills, T.M. Deficit irrigation in deciduous orchards. Hortic. Rev. 1997, 21, $105-130$.

15. Ebel, R.C.; Proebsting, E.L.; Evans, R.G. Deficit irrigation to control vegetative growth in apple and monitoring fruit growth to schedule irrigation. HortScience 1995, 30, 1229-1232.

16. Irving, D.E.; Drost, J.H. Effects of water deficit on vegetative growth, fruit growth and fruit quality in Cox's Orange Pippin apple. J. Hortic. Sci. 1987, 62, 427-432. [CrossRef]

17. Mpelasoka, B.; Behboudian, M.; Green, S. Water use, yield and fruit quality of lysimeter-grown apple trees: Responses to deficit irrigation and to crop load. Irrig. Sci. 2001, 20, 107-113.

18. Leib, B.G.; Caspari, H.W.; Redulla, C.A.; Andrews, P.K.; Jabro, J.J. Partial rootzone drying and deficit irrigation of "Fuji" apples in a semi-arid climate. Irrig. Sci. 2006, 24, 85-99. [CrossRef]

19. O'Connell, M.G.; Goodwin, I. Responses of "Pink Lady" apple to deficit irrigation and partial rootzone drying: Physiology, growth, yield, and fruit quality. Aust. J. Agric. Res. 2005, 58, 1068-1076. [CrossRef]

20. Glenn, D.M. Particle film mechanisms of action that reduce the effect of environmental stress in "Empire" apple. J. Am. Soc. Hortic. Sci. 2009, 134, 314-321.

21. Glenn, D.M. Canopy gas exchange and water use efficiency of "Empire" apple in response to particle film, irrigation, and microclimatic factors. J. Am. Soc. Hortic. Sci. 2010, 135, 25-32.

22. Glenn, D.M.; Erez, A.; Puterka, G.J.; Gundrum, P. Particle films affect carbon assimilation and yield in “Empire” apple. J. Am. Soc. Hortic. Sci. 2003, 128, 356-362.

23. Glenn, D.M.; Puterka, G.J.; Drake, S.R.; Unruh, T.R.; Knight, A.L.; Baherle, P.; Prado, E.; Baugher, T.A. Particle film application influences apple leaf physiology, fruit yield, and fruit quality. J. Am. Soc. Hortic. Sci. 2001, 126, 175-181.

24. Davies, W.J.; Zhang, J. Root signals and the regulation of growth and development of plants in drying soil. Ann. Rev. Plant Physiol. Plant Mol. Biol. 1991, 42, 55-76. [CrossRef]

25. Al-Absi, K.M. Gas exchange, chlorophyll and growth response of three orange genotypes (Citrus sinensis [L.] Osbeck) to abscisic acid under progressive water deficit. Jordan J. Agric. Sci. 2009, 5, 421-433.

26. Du, Y.-L.; Wang, Z.-Y.; Fan, J.-W.; Turner, N.C.; He, J.; Wang, T.; Li, F.-M. Exogenous abscisic acid reduces water loss and improves antioxidant defence, desiccation tolerance and transpiration efficiency in two spring wheat genotypes subjected to a soil water deficit. Func. Plant Biol. 2013, 40, 494-506. [CrossRef]

27. Ma, X.; Ma, F.; Mi, Y.; Ma, Y.; Shu, H. Morphological and physiological responses of two contrasting Malus species to exogenous abscisic acid application. Plant Growth Regul. 2008, 56, 77-87. [CrossRef]

28. Wang, Z.; Huang, B.; Xu, Q. Effects of abscisic acid on drought responses of Kentucky bluegrass. J. Am. Soc. Hortic. Sci. 2003, 128, 36-41.

29. Waterland, N.L.; Campbell, C.A.; Finer, J.J.; Jones, M.L. Abscisic acid application enhances drought stress tolerance in bedding plants. HortScience 2010, 45, 409-413.

30. Kondo, S.; Sugaya, S.; Sugawa, M.; Ninomiya, S.; Kittikorn, M.; Okawa, K.; Ohara, H.; Ueno, K.; Todoroki, Y.; Mizutani, M.; et al. Dehydration tolerance in apple seedlings is affected by an inhibitor of ABA 8-hydroxylase CYP707A. J. Plant Physiol. 2012, 169, 234-241. [CrossRef] [PubMed] 
31. Jie, Z.; Yuncong, Y.; Streeter, J.G.; Ferree, D.C. Influence of soil drought stress on photosynthesis, carbohydrates and the nitrogen and phosphorus absorb in different section of leaves and stem of Fugi/M.9EML, a young apple seedling. Afr. J. Biotechnol. 2010, 9, 5320-5325.

32. Wang, Z.; Quebedeaux, B.; Stutte, G.W. Osmotic adjustment: Effect of water stress on carbohydrates in leaves, stems and roots of apple. Aust. J. Plant Physiol. 1995, 22, 747-754. [CrossRef]

33. Shellie, K.; Glenn, D.M. Wine grape response to foliar particle film under differing levels of preveraison water stress. HortScience 2008, 43, 1392-1397.

34. Shellie, K.C.; King, B.A. Kaolin-based foliar reflectant and water deficit influence Malbec leaf and berry temperature, pigments, and photosynthesis. Am. J. Enol. Vit. 2013, 64, 223-230. [CrossRef]

35. Lawlor, D.W.; Cornic, G. Photosynthetic carbon assimilation and associated metabolism in relation to water deficits in higher plants. Plant Cell Environ. 2002, 25, 275-294. [CrossRef] [PubMed]

36. Zhang, B.; Archbold, D.D. Water relations of a Fragaria chiloensis and a F. virginiana selection respond to water deficit stress. J. Am. Soc. Hortic. Sci. 1993, 118, 280-285.

37. Tandon, H.L.S. Methods of Analysis of Soils, Plants, Waters and Fertilizers; Fertilizer Development and Consultation Organization: New Delhi, India, 1995; pp. 49-82.

38. Reddy, A.R.; Chaitanya, K.V.; Vivekanandan, M. Drought-induced responses of photosynthesis and antioxidant metabolism in higher plants. J. Plant Physiol. 2004, 161, 1189-1202. [CrossRef]

39. Misra, A.K.; Das, B.K.; Datta, J.K.; De, G.C. Influence of antitranspirants on photosynthesis, leaf dry wt., nitrate reductase activity and leaf yield of mulberry (Morus alba L.) under water stress condition. Indian J. Agric. Res. 2009, 43, 144-147.

40. Grange, M.; Wand, S.J.; Theron, K.L. Effect of kaolin applications on apple fruit quality and gas exchange of apple leaves. Acta Hortic. 2004, 636, 545-550. [CrossRef]

41. Prive, J.P.; Russell, L.; LeBlanc, A. The impact of kaolin clay sprays on leaf gas exchange of Ginger Gold apple trees in New Brunswick. Can. J. Plant Sci. 2006, 86, 1377-1381. [CrossRef]

42. Lombardini, L.; Glenn, D.M.; Harris, M.K. Application of kaolin-based particle film on pecan trees: Consequences on leaf gas exchange, stem water potential, nut quality, and insect populations. HortScience 2004, 39, 857-858.

43. Rosati, A.; Metcalf, S.G.; Buchner, R.P.; Fulton, A.E.; Lampinen, B.D. Physiological effects of kaolin applications in well-irrigated and water-stressed walnut and almond trees. Ann. Bot. 2006, 98, 267-275. [CrossRef] [PubMed]

44. Wunsche, J.N.; Lombardini, L.; Greer, D.H. Surround particle film applications-Effects on whole canopy physiology of apple. Acta Hortic. 2004, 636, 565-571. [CrossRef]

45. Demmig-Adams, B.; Adams, W.W.; Grace, S.C. Physiology of light tolerance in plants. Hortic. Rev. 1997, 18, 215-246.

46. Johnson, J.D.; Tognetti, R.; Paris, P. Water relations and gas exchange in poplar and willow under water stress and elevated atmospheric $\mathrm{CO}_{2}$. Physiol. Plant. 2002, 115, 93-100. [CrossRef] [PubMed]

47. Shao, H.; Chu, L.; Jaleel, C.A.; Zhao, C. Water-deficit stress-induced anatomical changes in higher plants. Plant Biol. Path. 2008, 331, 215-225. [CrossRef] [PubMed]

48. Cabuslay, G.S.; Ito, O.; Alejar, A.A. Physiological evaluation of responses of rice (Oryza sativa L.) to water deficit. Plant Sci. 2002, 63, 815-827. [CrossRef]

49. Nilsen, E.T.; Orcutt, D.M. The Physiology of Plant under Stress; John Wiley and Sons: New York, NY, USA, 1996.

50. Zeevaart, J.A.D.; Creelman, R.A. Metabolism and physiology of abscisic acid. Ann. Rev. Plant Physiol. Plant Mol. Biol. 1998, 39, 439-473. [CrossRef]

(C) 2016 by the authors; licensee MDPI, Basel, Switzerland. This article is an open access article distributed under the terms and conditions of the Creative Commons Attribution (CC-BY) license (http://creativecommons.org/licenses/by/4.0/). 